\title{
The Great Leap Offshore: Sino-Norwegian Relations and Petro-Knowledge Transfers, 1976-1997
}

Jonas Fossli Gjersø

\begin{abstract}
China's reemergence among the world's leading economic and political powers has been one of the most defining changes in the international order since the end of the Cold War. Underpinning China's ascent were the economic reforms instituted across the late 1970 s and early 1980 s that opened its economy to foreign direct investments. Preceding these reforms were the ambitions entertained for China's continental shelf, optimistically forecasting it as nothing less than "the world's richest petroleum reservoir." This article will attempt to link these phenomena by examining the economic readjustment in conjunction with the capital-and technology-intensive requirements of the offshore oil industry. It will explore how petroleum knowledge was diffused between Norway and China: notably, how Chinese reformers abandoned the Daqinigst doctrine of self-reliance in favor of a hybrid Norwegian model of petroleum governance. Even though exploration efforts proved disappointing, the episode had both long-term political and commercial ramifications. It was during this often-overlooked episode of Chinese, international, and indeed Norwegian petroleum history that Norway's national oil company, Statoil, took its first steps outside the Norwegian continental shelf and inspired the formation of China's own national offshore oil company, China National Offshore Oil Corporation.
\end{abstract}

Keywords: Chinese Oil History, National Oil Companies, Sino-Norwegian Relations, China

\section{Introduction}

In November 2021, China's Communist Party passed its third historical resolution in its 100-year history. Whereas the 1981 resolution strongly criticized the former Maoist regime's Cultural Revolution as a "comprehensive, long-drawn-out and grave blunder," the party under the leadership of Xi Jinping offered little but praise for Deng Xiaoping’s flagship "reform and opening-up" initiative. ${ }^{1}$ In fact, it was held that "the Party and the people [had] showed the

1. "Resolution on Certain Questions in the History of Our Party Since the Founding of the People's Republic of China," adopted by the Sixth Plenary Session of the Eleventh Central Committee of the Communist Party of China on June 27, 1981, p. 8. https://www.marxists.org/subject/china/documents/cpc/history/01.htm.

(c) The Author(s), 2022. Published by Cambridge University Press on behalf of the Business History Conference. All rights reserved. This is an Open Access article, distributed under the terms of the Creative Commons Attribution licence (https://creativecommons.org/licenses/by/4.0/), which permits unrestricted re-use, distribution, and reproduction in any medium, provided the original work is properly cited. 
world that reform and opening up was a crucial move in making China what it is today," and it was resolved that "reform and opening up ... should [...] deepen across the board." 2 This reasserted commitment to a set of policies that emerged in the late 1970s demonstrates not only their continued relevance but warrants a fuller understanding of their origins, some of which can be traced back to China's efforts at developing its capital-and technology-intensive offshore sector in the 1970s to the 1980s.

A 1960s roughneck awakening from a Rip van Winkle sleep in the 2020s would doubtless have been astounded by the changes wrought in the industry. In the space of just six decades, both the pattern of global oil trade and the structure of the international oil industry have undergone a revolution. The United States has been eclipsed by China as the world's largest oil importer; and the erstwhile "Seven Sisters" iron grip on oil's upstream has been broken by a vanguard of national champions, ranging from China National Offshore Oil Corporation (CNOOC) to Norway's Equinor (hereafter Statoil). ${ }^{3}$ The purpose of this article is to explore the links between these seemingly unrelated processes by examining Sino-Norwegian relations and the operations of Statoil in China during the 1970s through the 1990s. The offshore knowledge transfers and foreign direct investments made in this era of "reform and opening up" contributed to China's economic transformation and inspired the formation of its own offshore national oil company (NOC). It also exerted a profoundly transformative effect upon one of the agents participating in and fomenting this process, representing as it did the start of Statoil's international expansion.

The Organization of Oil Exporting Countries' (OPEC) oil embargo in October 1973 spurred the international oil companies (IOCs) into a search for alternative petroleum provinces. Famously, the North Sea benefited from this realignment of upstream investments, situated as it was in low-risk jurisdictions and near consuming markets. Less well known is how the oil crisis also led to an urgency about developing the hydrocarbon potential of its Far Eastern equivalent, both among western oil companies and important sections of China's political elite. Premier Zhou Enlai's 1973 decision to export crude to finance China's wider modernization betrayed a movement away from orthodox Maoism, a schism in the ruling Communist Party that was to come to full fruition at the end of the decade. ${ }^{4}$ After Mao Zedong's death in 1976, Hua Guofeng's successor government called for a "New Great Leap" by redoubling the emphasis on petroleum production, particularly offshore-a policy that was sustained by Zhou's protégé Deng. ${ }^{5}$

Offshore oil production was pioneered in the Mexican Gulf in the 1940s, but as a relatively new technique, it was capital intensive and technologically demanding, positioning the IOCs

2. "Communiqué of the Sixth Plenary Session of the 19th Central Committee of the Communist Party of China," adopted at the Sixth Plenary Session of the 19th Central Committee of the Communist Party of China on November 11, 2021. http://www.news.cn/english/2021-11/11/c_1310305166.htm.

3. Known as "Den norske stats oljeselskap A/S" (abbreviated "Statoil") from its founding in 1972 to its merger with Norsk Hydro's Oil and gas division in 2007, after which it was branded "StatoilHydro.” It reverted to "Statoil" in 2009 until it underwent a rebranding to "Equinor" in 2018. It is also worth noting that other factors, such as the rise of specialist oil field service companies, broke the international oil companies' technological stranglehold, enabling the NOCs' rise. See Stevens, “International Oil Companies,” 6.

4. Hong-Pyo, "China's Petroleum Trade," 188-199.

5. Lieberthal and Oksenberg, Policy Making in China, 205-219. 
as its gatekeepers. Yet, due to the knowledge transfers inherent to the participation model of concession regimes, their technological oligopoly was increasingly challenged during the 1970s by a new cadre of resource-holding and market-seeking NOCs, one of which was the newly formed Den norske stats oljeselskap AS, or Statoil. To leading members of China's socalled "petroleum faction," social-democratic Norway's model of resource governance represented an attractive method of negotiating with the predominantly American corporations and a way in which to reconcile China's doctrine of self-reliance with the need for advanced technology and capital, while to Norwegian authorities, China represented a burgeoning market for its infant offshore services industry.

Building upon Lieberthal and Oksenberg's seminal study into Chinese policy making between 1977 and 1986, recently released Norwegian diplomatic files, and Statoil's corporate archive, this article will investigate how and why Norwegian and Chinese petroleum interests converged, emphasizing Norway's role in the development of China's offshore sector and governance model. ${ }^{6}$ In addition to illuminating this little-known episode in the history of Sino-Norwegian relations, it is is hoped this analysis will illustrate both how petro-knowledge was diffused between two oil-producing states and the political origins of NOC internationalization. Reflecting the sequence of events and for reasons of clarity, the analysis is divided into three distinct sections.

The first section details the development and status of the Chinese petroleum sector; the second concerns the convergence between Sino-Norwegian petroleum interests on a political level, how the "Norwegian model" of petroleum governance was transmitted and partially adopted by China; notably how China abandoned its doctrine of self-reliance and how Statoil served as inspiration for the formation of CNOOC. ${ }^{7}$ The third and final section will attempt to show how Statoil's role in this bilateral relationship evolved from that of policy tool to that of an agent with ambitions developed independently of its state owner. Importantly, the article will demonstrate how Statoil was granted a general permission to operate outside the Norwegian continental shelf (NCS) as a function of its China engagement, specifically in order to participate in China's second licensing round.

\section{A "Great Joy": China's Oil Industry}

As the world reeled from the economic effects of OPEC's oil embargo over the autumn months of 1973, NATO prepared a report entitled "the prospects for China's oil industry." It concluded that China "probably had considerable offshore reserves," but that technological and political problems prevented their exploitation. ${ }^{8}$ Over the next decade, both the technical and the political problems were overcome, but the question remained as to whether the Bay of Bohai or the Yellow Sea harbored reserves akin to the Mexican Gulf or the North Sea.

6. Lieberthal and Oksenberg, Policy Making in China, 169-268.

7. Kang Shien to Hans Henrik Ramm, March 21, 1982, Olje- og energisamarbeid Norge-Kina Bind 4, 1981-83, Utenriksdepartementets arkiv.

8. NATO Report, “The Prospects for China’s Oil Industry,” November 1973, Olje- og naturgassutvinning, Kina 1970-78, Dbd-L3739, Riksarkivet. 
While the People's Republic of China (PRC) only had modest experience of offshore operations, it was certainly not a newcomer to the oil industry. ${ }^{9}$ Japanese technicians sank the first oil well in the Shaanxi Province in 1907, a contract that the Republic of China renewed with Mobil Oil Corporation in 1914. ${ }^{10}$ Three years of exploration proved unsuccessful, however, and China was deemed an “oil-poor” region. China's fortunes changed in the midtwentieth century, when significant oil discoveries were made: Laojunmiao in 1940 and Songliao in 1959, the latter of which formed the backbone of China's oil industry. The promising results of No. 3 Songji well just four days before the Communist revolution's tenth anniversary served as the inspiration for its name Daqing or "Great Joy."11

Across the 1960s, Daqing became a veritable Far Eastern Spindletop, accounting for 67.9 percent of total crude output when Premier Zhou Enlai declared China self-sufficient in 1963. ${ }^{12}$ Two decades later, the field still provided more than half of Chinese production, but the volume had increased almost twentyfold. ${ }^{13}$ The Ministry of Petroleum Industry (MPI) was responsible for these increases, which propelled total Chinese production from 227,000 barrels per day (bbl/d) in 1965 to $2.1 \mathrm{million} \mathrm{bbl} / \mathrm{d}$ in 1979. China thus emerged over the course of the 1970s as one of the world's top ten crude oil producers and, as a means of earning foreign currency, a net exporter. ${ }^{14}$

Hitherto China's oil industry had been exclusively land-based, yet it was its continental shelf that seemed the most promising for boosting production in the early 1970s. Some attempts at exploratory drilling off Hainan had been made from 1959 onward, and for almost a decade in the Bay of Bohai using floats, but neither met with much success. ${ }^{15}$ Due to their proximity, Japan had speculated in China's offshore potential, and with a view to exploration

9. Drilling for oil and natural gas was pioneered in China over two millennia ago, during the Warring States Period. In the ancient Zhou dynasty, oil was used as "dragon ointments," in the late Han dynasty as lubricants, in the Song dynasty as incendiary weapons, and when refining was developed in the Ming dynasty, as lamp oil. Yet it was not until Edwin Drake's innovation of combining Chinese drilling techniques with steam power that petroleum emerged as a commodity on an industrial scale. See Feng et al., The Chinese Oil Industry, 2-3; Hobson, The Eastern Origins of Western Civilisation, 215.

10. Feng et al., The Chinese Oil Industry, 4.

11. Kambara and Howe, China and the Global Energy Crisis, 13-14.

12. Lim, Oil in China, 18-19.

13. Lim, Oil in China, 22; Kambara and Howe, China and the Global Energy Crisis, 19. From 5.2 million tonnes in 1960 to 104.1 million tonnes in 1978. Also memorandum, "Folkerepublikken Kinas energisituasjon," May 28, 1980, Olje- og energisamarbeid Norge og Kina, Bind 3, 1980, Utenriksdepartementets arkiv. Chinese annual crude oil production in million tonnes: 1949: 0.1; 1959: 5; 1965: 11; 1970: 28; 1975: 74; 1977: 90; 1978: 100; 1979: 104.

14. Kambara, “The Petroleum Industry in China,” 711-718; BP, Statistical Review of World Energy 2021. Chinese crude oil production in million tonnes 1970: 30.7 (1.3 percent of world output); $1971: 39.4$ (1.58 percent); 1972 : 45.7 (1.73 percent); $1973: 53.61$ (1.86 percent); $1974: 64.85$ (2.25 percent); $1975: 77.06$ (2.93 percent); 1976: 87.16 (2.93 percent); 1977: 93.64 (3.04 percent); 1978: 104.1 (3.35 percent); 1979 : 106.2 (3.28 percent). Feng et al., The Chinese Oil Industry, 6. China was the sixth- and eighth-largest oil producer in 1971 and 1975, respectively. Also NATO Report, “The Prospects for China’s Oil Industry,” November 1973, Olje- og naturgassutvinning, Kina 1970-78, Dbd-L3739, Riksarkivet.

15. Li to Hveding, minutes of meeting between Norway's minister of oil and energy Vidkunn Hveding and China's minister of petroleum industries Li Tianxiang, September 7, 1982, Olje- og energisamarbeid Norge-Kina Bind 4, 1981-83, Utenriksdepartementets arkiv; Qin to Hveding, minutes of meeting between Norwegian minister for oil and energy Vidkunn Hveding and CNOOC president Qin Wen Cai, September 8, 1982, Oljeog energisamarbeid Norge-Kina Bind 4, 1981-83, Utenriksdepartementets arkiv. 
drilling, sold China the drillship Pailung in 1969, followed in 1972 by the drillship Fuji, a jackup rig, and a semi-submersible rig. ${ }^{16}$ NATO's report nonetheless criticized the Chinese government for its putative unwillingness to deploy foreign technology and capital adequate for the "massive effort" involved in turning the country into an oil exporter of any real significance. ${ }^{17}$

This "unwillingness" NATO alluded to was more than a bureaucratic oversight; it derived from the very center of the Communist Party's factional strife in the late Mao years. Daqing's significance had not been limited to enhancing China's oil output; it had also given rise to an ideological notion of self-sufficiency and economic development through mobilization of manpower in "battle formations": the "Daqing method" or "Daqingism."18 The Sino-Soviet split had elevated Daqing's importance to that of a Maoist model industry and an "affirmation of Maoist ideology," a symbolic role that was further entrenched during the Cultural Revolution and its method applied with varying degrees of success across the Chinese economy. ${ }^{19}$ In tandem with the illusion of autarky, it empowered the group of technocrats that had been set to manage the field, the so-called "Petroleum Faction," whose pragmatism ultimately proved Daqingism's undoing.

Mao had assigned the running of the field, and by extension the country's oil industry, to a select group of officials, which included Yu Qiuli, Gu Mu, Tang Ke, and Kang Shien. ${ }^{20}$ While not insulating the leaders from the purges inflicted across China's structures of state during the Cultural Revolution, the oil industry's success and strategic importance tempered the Red Guards' severity: all of whom were removed in 1967 but swiftly reinstated between 1969 and $1970 .{ }^{21}$ In the twilight of Mao's chairmanship, several factions had emerged vying for the party's control, one of these powerful groups was the so-called "Oil Kingdom Faction." 22 This "oil clique" occupied the political middle ground between the orthodox Maoists such as Hua Guofeng and Ye Jianying to the left and the rehabilitated victims of the Cultural Revolution to the right, notably Zhou Enlai's reformist faction, the leadership of which was assumed by Deng Xiaoping in 1977 after Zhou's death in $1976 .{ }^{23}$ China's petroleum industry thus represented an

16. Thorleiv Anda to Utenriksdepartementet, "Chinas offshore aktivitet,” October 15, 1975, Dbd-L3739, Riksarkivet; and Willy Fredriksen to Utenriksdepartementet, "Chinas oljeproduksjon-Drillskip og oljeledning,” January 13, 1975, Olje- og naturgassutvinning, Kina 1970-78, Dbd-L3739, Riksarkivet.

17. NATO Report, Olje- og naturgassutvinning, Kina 1970-78, Dbd-L3739, Riksarkivet.

18. Lim, Oil in China, 37; Kambara and Howe, China and the Global Energy Crisis, 14-17.

19. Chan, The Taching Oilfield, 5-8, 11-14; Hama, The Daqing Oilfield, 180-183, 186-189, 193-203.

20. , China and the Global Energy Crisis, 25-26; Lieberthal and Oksenberg, Policy Making in China, 35-40, 44-48, 60. Kambara and Howe offer an excellent analysis of China's energy bureaucracy, including exhaustive biographies of Kang Shien and Tang Ke. The discovery and development of Daqing took place during Yu's tenure as minister of petroleum industry, a position that both Tang and Yu's protégé Kang would occupy after the ministry's reinstatement in 1975. See also description of China's petroleum administration: "Beskrivelse av kinesisk oljeadministrasjon," November 9, 1982, Olje- og energisamarbeid Norge-Kina Bind 4, 1981-83, Utenriksdepartementets arkiv. Brødsgaard, "Moving Ahead in China," 107-122, offers a study into how China's petroleum industry represents a powerful political platform within the Chinese Communist Party from the late 1970s onward.

21. Lieberthal and Oksenberg, Policy Making in China, 44-51; Chan, Taching Oilfield, 17-19; Kambara and Howe, China and the Global Energy Crisis, 25.

22. Fontana, "Fall of Hua Guofeng," 239, 244; Lieberthal and Oksenberg, Policymaking in China, 58-62.

23. Fontana, "Fall of Hua Guofeng," 245-254. 
ideological battleground and an important source of political influence, its fortunes to some extent swaying the Communist Party's balance of power. ${ }^{24}$

The first oil crisis had focused Western attention on China's potential as an alternative petroleum province and identified the principal challenges of developing it. Technology and capital were readily available from Western IOCs, but the question remained as to whether Mao's regime would open its strategic petroleum sector to foreign investments. Contemporary observers presumed that if China was to pursue an offshore strategy, the capital- and technology-intensive nature of offshore oil production would inexorably force the country on a pathdependent progression toward a more general trade liberalization. ${ }^{25}$

\section{Scrambling for "the World's Richest Petroleum Reservoir"}

In sharp contrast to the oil market stability enjoyed in the 1960s, when crude prices had averaged at $\$ 1.8$ per barrel, the 1970s brought acute supply shortages and price shocks. The first oil crisis in 1973 propelled the cost of crude oil over sixfold to $\$ 11.58$. Prices plateaued until 1979, when the Iranian Revolution and the second crisis drove them even higher, to an almost unprecedented $\$ 31.61$ per barrel. ${ }^{26}$ The dramatic volatility of the 1970 s lent a sense of urgency on behalf of consuming countries and the IOCs, while strengthening the hands of reserve-holding governments.

Reserve estimates entertained for China's continental shelf were similarly inflated. Observers in 1975 believed offshore exploration would double China's potential reserves to 50 billion barrels. ${ }^{27}$ Five years later, as twenty European, American, and Japanese oil companies were conducting seismic exploration off Bohai Bay, the Yellow Sea, the East and South China Seas, and Tonkin Bay, this estimate was redoubled to a potential 100 billion barrels. ${ }^{28} \mathrm{In}$ fact, the continental shelf between Taiwan and Japan alone was presumed by experts in the UN's Economic Commission for Asia and the Far East to be nothing less than the "world's richest petroleum reservoir."29

Chinese inexperience in offshore exploration, transport, and production was a vacuum the global oil industry was eager to fill. ${ }^{30}$ From 1974 to 1976, a range of countries had made

24. Lieberthal and Oksenberg, Policymaking in China, 58-62.

25. China og oljevåpenet, January 20, 1975, Dbd-L3739, Kina-Olje og naturgassutvinning i fremmede land, Utenriksdepartementets arkiv. See also Utenriksdepartementet memorandum, "Bakgrunnsnotat, norsk undersøkelsesvirksomhet på omstridt sokkelområde. Noen problemstillinger,” September 5, 1980, Olje- og energisamarbeid Norge og Kina, Bind 3, 1980, Utenriksdepartementets arkiv.

26. BP, Statistical Review of World Energy 2021.

27. Stein Seeberg to Utenriksdepartementet, August 13, 1975, Olje- og naturgassutvinning, Kina 1970-78, Dbd-L3739, Riksarkivet.

28. Norwegian embassy in Beijing to Utenriksdepartementet, "Kinesisk olje, sluttrapport,” May 9, 1980, Olje- og energisamarbeid Norge og Kina, Bind 3, 1980, Utenriksdepartementets arkiv.

29. Stein Seeberg to Utenriksdepartementet, August 13, 1975, Olje- og naturgassutvinning, Kina 1970-78, Dbd-L3739, Riksarkivet; Ling, The Petroleum Industry in the People's Republic of China, 57: "Special emissary to Peking, Henry Kissinger, proposed to premier Chou En-lai in September of that year that the United States cooperate with China in exploring the petroleum resources of the Po-hai Gulf area, which was reputed to be the richest in the world, with nearly ten times the volume of reserves in the Persian Gulf." See also Högselius. "The Saudi Arabia of the Far East?,” 414; Eckbo, The Future of World Oil, 56.

30. Stein Seeberg to Utenriksdepartementet, August 13, 1975, Olje- og naturgassutvinning, Kina 1970-78, Dbd-L3739, Riksarkivet. 
representations to the PRC for the privilege of selling it equipment. In 1974, China purchased American exploration and drilling equipment for \$10 million, while a French oil company had gained a contract worth $\$ 4.7$ million for exploring the Yellow Sea. Jardine Matheson \& Company of Hong Kong sold drillships and pipe-laying equipment, while Japan’s Mitsubishi \& Nippon Steel had acquired a similar order to the value of \$100 million. ${ }^{31}$ In March 1976, the Dutch entered the fray by dispatching an industrial delegation. Chinese authorities were, however, not receptive to the idea of hosting another group of sales representatives and demanded that the delegation consist of scientists and practitioners relevant to offshore industry. ${ }^{32}$

Despite the Dutch experts' visit, the MPI did not commit to making any purchases but kept the possibility open once it had considered all its options. ${ }^{33}$ These were presented by a wide variety of competing nations: Belgium, France, the German Democratic Republic, Sweden, and Denmark all followed suit in organizing or planning symposia concerning various aspects of the sector in order to position themselves for future Chinese orders. The timing was of particular importance, because the fifth five-year plan was about to be concluded. ${ }^{34}$ Missing from this list of interested parties was Norway, a fact regretted by its ambassador Torleiv Anda, who implored Norwegian business interests to keenly monitor other nations' advances toward the Chinese offshore industry. He warned that neither "the Japanese, Americans nor British would remain passive. Norway ought to [...] assume a more active stance, by for instance, proposing to hold an offshore symposium for Chinese oil experts." ${ }^{35}$ Ambassador Anda's patience would not be tried for long, as Norway dispatched a delegation of its own in early June 1976. ${ }^{36}$

Norway's relatively early recognition of the PRC in 1954 had ensured amicable relations with Mao's regime. ${ }^{37}$ Until the 1970s, Norwegian economic interests in the Far East derived almost exclusively from the activities of its merchant fleet. The advent of the North Sea oil boom and emergence of Japan as the world's shipbuilder led, however, to the reinvention of Norway's many shipyards as suppliers to the offshore industry. ${ }^{38}$ Thus, it was as purveyors of drilling platforms, cleaning equipment for oil spills, and a plethora of the offshore oil

31. Ibid.

32. Torleiv Anda to Utenriksdepartementet, April 6, 1976, Olje- og naturgassutvinning, Kina 1970-78, Dbd-L3739, Riksarkivet.

33. Ibid.

34. Ibid.

35. Ibid.

36. Norwegian Oil Delegation to China, memorandum, June 7-11, 1976, Olje- og naturgassutvinning, Kina 1970-78, Dbd-L3739, Riksarkivet.

37. Speech, "Toast by Vice-Premier Kang Shi'en at Dinner Given by Norwegian Prime Minister Odvar Nordli," June 10, 1980, Olje- og energisamarbeid Norge og Kina, Bind 3, 1980, Utenriksdepartementets arkiv: "Norway is an old friend of China’s." Also Foreign Secretary Knut Frydenlund, memorandum of a conversation with Kang Shien, confidential, June 16, 1980, "Norge-Kina. Visestatsminister Kang Shi'ens besøk i Norge 31. mai-8. juni. Samtale med utenriksminister Knut Frydenlund, mandag 2. Juni 1980,” Olje- og energisamarbeid Norge og Kina, Bind 3, 1980, Utenriksdepartementets arkiv; also minutes of meeting undertaken during Norvik's visit to China, "Hovedmøte med Ministry of Petroleum," June 20, 1981, Olje- og energisamarbeid Norge-Kina Bind 4, 1981-83, Utenriksdepartementets arkiv. Vice-Petroleum Minister Qin Wen-Cai is quoted as saying: "Norway was one of the first countries who recognized the PRC and the trade relations are good."

38. Vatten, Skipsbygging - en saga blott?, 13-28. 
industry's other services and impedimenta that Norway from 1976 onward asserted its presence in the region. The first of these active steps was the delegation, which over the next decade was followed by a range of visits by technical experts on hydropower and petroleum and, at the political level, by foreign secretaries, ministers for oil and energy, and all three serving prime ministers: Odvar Nordli, Kåre Willoch, and Gro Harlem Brundtland. ${ }^{39}$

The delegation's official report reflected the political crisis and doctrinal transition gripping China in the late 1970s. The Norwegian diplomats speculated about the reasons for their hosts' noncommitment and thought that "the battle between the so-called moderate and radical factions [...] seemed to have paralysed the country's ability to make political decisions." 40 They deemed China's bureaucracy to be largely sympathetic to the "pragmatic economic policies represented by Deng Xiaoping” but noted that the "daily criticism levelled against his so-called capitalist approach made them [Chinese bureaucrats] unable to take a definitive stand." 41

The report was overall rather doubtful about the commercial opportunities for Norwegian firms. The Chinese were considered slow in developing their offshore sector, and Norway's large trade surplus with China had attracted the disapproval of PRC officials. Finally, the delegates warned against the Chinese practice of copyright infringement. Thought to be a consequence of its self-reliance policies, it would typically manifest itself through the "purchasing of a single item of relatively advanced equipment, its dismantlement and the production of its own version." ${ }^{42}$ Naturally, this posed an unattractive proposition for a budding exporter of technologically advanced capital. Many Western countries were competing for the same contracts, and the Chinese did not appear to be pressed for time. The Norwegian diplomats' rather bland advice for any company vying for contracts was to have patience and offer competitively priced products.

Yet the delegation's projections proved pessimistic. Due to a fall in output from fields onshore, the Chinese sought to compensate by expanding their production portfolio to deep-water drilling. ${ }^{43}$ China produced 2.1 million $\mathrm{bbl} / \mathrm{d}$ in 1978 , and its aim was to increase this to around 8.4-10.6 million $\mathrm{bbl} / \mathrm{d}$, of which $3 \mathrm{million} \mathrm{bbl} / \mathrm{d}$ would derive from offshore production. ${ }^{44}$ While crude production had increased by 11 percent in 1978 to 2.1 million

39. Per Ravne, memorandum, “Oljepolitiske spørsmål,” March 1, 1978, Olje- og energisamarbeid NorgeKina 1970-79, Bind 2, Riksarkivet.; see also memorandum, "Samarbeide med Kina innen energi- og petroleumssektoren, May 14, 1980, Olje- og energisamarbeid Norge og Kina, Bind 3, 1980, Utenriksdepartementets arkiv; Gunnar Rustekaas to Utenriksdepartementet, memorandum, October 6, 1983, Olje- og energisamarbeid Norge og Kina, Bind 5, 1983-86, Utenriksdepartementets arkiv.

40. "Summary and Conclusion to the Norwegian Delegation's Visit to Peking," June 21, 1976, Olje- og naturgassutvinning, Kina 1970-78, Dbd-L3739, Riksarkivet.

41. Ibid.

42. Ibid.

43. Stein Seeberg to Utenriksdepartementet, July 5, 1977, Olje- og naturgassutvinning, Kina 1970-78, DbdL3739, Riksarkivet.

44. Aarnes to Utenriksdepartementet, minutes from meeting between Norwegian ambassador Tancred Ibsen and trade secretary Aarnes with China's vice-minister of petroleum Chin Wen-Chi, October 16, 1979, Oljeog naturgassutvinning, Kina 1970-78, Dbd-L3739, Riksarkivet. 
$\mathrm{bbl} / \mathrm{d}$, the following year's production increase had all but stagnated at 1.9 percent, increasing the deep-water impetus. ${ }^{45}$

Experts estimated that China in 1978 occupied the same technological stage in terms of drilling equipment and other oil production gear as the United States did in the late 1940s. Most of it consisted of old infrastructure purchased from the Soviet Union and Romania before the Sino-Soviet split. ${ }^{46}$ To overcome this threshold, China sent fact-finding missions to a select few countries that possessed the requisite technology: Japan, the United States, the United Kingdom, France, and Norway. ${ }^{47}$ To attract Chinese custom, American suppliers such as General Electric, Ingersoll Rand, and Caterpillar attempted to reconcile Maoist self-reliance with foreign imports by offering to train the Chinese personnel in not only using, but also in designing their equipment-a form of help to self-help. ${ }^{48}$ This strategy seems to have borne fruit, as yet another Chinese order was placed for a drilling platform with an American supplier, and as will be demonstrated, was an approach adopted and deployed in modified form by the Norwegian government in its own export drive. ${ }^{49}$

Following Mao's death and the arrest of the Gang of Four in the autumn of 1976, Hua Guofeng assumed the party's chairmanship by Politburo resolution. ${ }^{50}$ Hua had emerged from a leftist faction but had soon moved toward the center, distancing himself from the Cultural Revolution's secret police in early 1977 and building a fragile coalition with the hard-line Maoist “Whateverists," Long March veterans, and the moderate petroleum faction. ${ }^{51}$ Hua's reign was, however, short-lived. The failure of his ten-year plan, which relied heavily on increasing Chinese oil production along Daqingist lines, and insistence on Maoist orthodoxy led to his de facto ousting in December $1978 .{ }^{52}$ China had by the end of Hua's time in power amassed the largest trading deficit for decades, and the petroleum exploration efforts in Bohai Bay and Western China had proven unable to stem the stagnation in domestic oil production. ${ }^{53}$ It was under these circumstances that a delegation from the Norwegian Water Resources and Energy Directorate (NVE), who in the spring of 1978 had visited China to consult on hydroelectric dam construction projects, was asked whether Norway also could assist in developing China's petroleum sector. ${ }^{54}$

45. Norwegian embassy Beijing to Utenriksdepartementet, memorandum, May 5, 1980, Olje- og energisamarbeid Norge og Kina, Bind 3, 1980, Utenriksdepartementets arkiv. China produced in 1978 around 2 million $\mathrm{bbl} / \mathrm{d}$, half of which derived from the Daqing field, with the remainder sourced from Danang, Shenglai, and offshore Bohai.

46. Harald Svanøe Midttun to Utenriksdepartementet, memorandum, "Lecture in Houston entitled 'Oil and Gas in China,”’ December 11, 1979, Olje- og naturgassutvinning, Kina 1970-78, Dbd-L3739, Riksarkivet.

47. Kambara and Howe, China and the Global Energy Crisis, 28.

48. Stein Seeberg, “Technical problems a liability for Chinese offshore activities,” July 11, 1977, Olje- og naturgassutvinning, Kina 1970-78, Dbd-L3739, Riksarkivet.

49. "US Catches China's Eye,” Far Eastern Economic Review, April 28, 1978; “Americans Cash in on China Oil Boom,” South China Morning Post, April 20, 1978.

50. Fontana, "Fall of Hua Guofeng," 245.

51. Fontana, "Fall of Hua Guofeng," 244.

52. Fontana, "Fall of Hua Guofeng," 244; Zhang, Ideology and Economic Reform Under Deng Xiaoping, 20. Hua endorsed Kang Shien's 1977 proposal of a twelve-fold increase in Chinese oil production ("a dozen Daqings") by the end of the twentieth century, see: Mao, The Ebb and Flow of Chinese Petroleum,222-223.

53. Patey, The New Kings of Crude, 86; Vogel, Deng Xiaoping, 190.

54. Bjartmar Gjerde to the Norwegian government, Notat til regjeringskonferanse September 3, 1980, Dc 0001, Bjartmar Gjerde’s Papers, Arbeiderbevegelsens arkiv og bibliotek. 


\section{A Sino-Norwegian Petro-Rapprochement: Knowledge Transfers between Oil-producing States, 1978-1983}

If the late 1970s represented a period of relative stagnation for China's offshore oil industry, its Far Western equivalent was undergoing a boom. As a corporate manifestation of the state's participation rights in hydrocarbon production on the NCS, a unanimous Norwegian parliament established Den norske stats oljeselskap A.S., or Statoil, in $1972 .{ }^{55}$ Despite the large construction projects underway on the NCS, Odvar Nordli's Labor government had by 1978 become worried about the long-term viability of the industry. ${ }^{56}$ Projections suggested that Norway would reach its maximum petroleum production rate in 1980-1981, at which time production would plateau and then "sharply fall from 1988 onwards." ${ }^{57}$ Coinciding with these predictions were data showing that exports from Norway's offshore supply industry had plummeted between 1975 and 1977.

The export of production platforms had slowed to but a trickle: the total value of Norwegian exports was NOK 2.3 billion in 1975, while the equivalent for 1977 was a paltry NOK 20 million. ${ }^{58}$ Across the North Sea, James Callaghan's Labour government had instituted protectionist policies through its Office of Offshore Supplies, which all but removed Norway's principal export market for its platforms. The minister for industry, Bjartmar Gjerde, recognized that Norway was hampered by both high wage costs and low levels of specialization due to lack of oil sector experience. ${ }^{59}$ Yet Gjerde announced that he would be seeking new markets for the country's suppliers, specifically identifying South America and China. ${ }^{60}$

In what in retrospect may seem a happy coincidence for the Norwegian oil industry, 1978 marked a watershed in China's modern political and economic history. The early failure of Hua's ten-year plan paved the way for Deng Xiaoping's ascendancy at the 3rd Plenary Session of the 11th Central Committee of the Communist Party of China in December 1978. ${ }^{61}$ Deng, who under the Cultural Revolution had officially been designated "China's capitalist lackey number 2" had from mid-1977 to the end of 1978 purged fifteen out of twenty pro-Hua provincial party committee first secretaries and replaced them with his own supporters. ${ }^{62}$ His rise marked the next step in China's doctrinal transition: from the Maoist Gang of Four's orthodox policies of self-reliance through Hua's embrace of a limited liberalization by

55. St.prp. 113 (1971/1972) Om opprettelse av Statens oljedirektorat og et statlig oljeselskap m.m.; S.tid. (1971/1972), ss. 3634-3674. Norwegian Parliamentary Records. See also Thomassen, "The Crude Means to Mastery," 81-91.

56. Gordon and Stenvoll, Statoil, 22.

57. Bjartmar Gjerde to the Norwegian government, Notat til regjeringskonferanse, May 29, 1978, Dc 0001, Bjartmar Gjerde’s Papers, Arbeiderbevegelsens arkiv og bibliotek. “[...] etter 1988 er kurven sterkt fallende.”

58. Bjartmar Gjerde to the Norwegian government, Notat til regjeringskonferanse, May 26, 1978, Dc 0001, Bjartmar Gjerde's Papers, Arbeiderbevegelsens arkiv og bibliotek. 1975: NOK 2.352 billion; 1976: NOK 859 million; 1977: NOK 20 million.

59. Ibid.

60. Ibid.

61. Vogel, Deng Xiaoping, 245-248.

62. Lim, Oil in China, 115; Tancred Ibsen to Utenriksdepartementet, March 10, 1980, confidential, Olje- og energisamarbeid Norge og Kina, Bind 3, 1980, Utenriksdepartementets arkiv. Liu Shaoqi was designated as "China’s capitalist lackey number 1." 
adopting policies from Yugoslavia and Romania, which accepted foreign currencies, technology, and joint ventures with foreign companies, toward Deng's reform and opening up program. ${ }^{63}$

Gjerde visited the country November 11-24, 1978, and met with Vice-Premier and Chairman of the State Economic Commission Kang Shien, Minister of Petroleum Sung Che-ming and Deputy Minister Chang Wenpin. ${ }^{64}$ Importantly, on his return visit to Norway in 1980, Kang made clear to Prime Minister Nordli that Gjerde's visit marked a "turning point" in China's petroleum policy, because it was the first time China had cooperated with a foreign state with regard to its oil sector. ${ }^{65}$ As Yu Qiuli's protégé, the minister for petroleum in the crucial years 1958-1965 when Daqing was discovered and developed, Kang was certainly well placed to pronounce the end of orthodox Daqingism. ${ }^{66}$

In anticipation of a rich new oil province, NOCs, such as Total, Elf, and Japex Daqing and IOCs, including BP, Chevron, Texaco, Esso, Mobil, Phillips, Amoco Orient, Occidental, and Arco, had all been attracted to China and were positioning themselves for licenses in the first offshore concession round. ${ }^{67}$ Norway had two areas of expertise that proved to be of interest to the Chinese hosts: experience of hydropower production and a new, but significant offshore oil and gas sector governed by a sophisticated three-pronged bureaucratic structure retrospectively dubbed "the Norwegian model." ${ }^{68}$ What seemed particularly attractive was Norway's relationship with the IOCs, whereby it retained sovereign control over resources while using the companies' capital and expertise to develop the country's petroleum sector.

63. Vogel, Deng Xiaoping, 189-190; Lim, Oil in China, 115. Hua formally retained his position as premier and Deng as his vice-premier and vice-party chairman, but this was in name only. See Foreign Office memorandum, "Visitt hos Utenriksministeren 2. juni 1980," May 29, 1980, Olje- og energisamarbeid Norge og Kina, Bind 3, 1980, Utenriksdepartementets arkiv. Also conversation with Prime Minister Nordli, June 2, 1980, Oljeog energisamarbeid Norge og Kina, Bind 3, 1980, Utenriksdepartementets arkiv; Tancred Ibsen to Utenriksdepartementet, Memorandum, "Kinas utviklingstendenser," March 24, 1980, Olje- og energisamarbeid Norge og Kina, Bind 3, 1980, Utenriksdepartementets arkiv.

64. Gjerde, Regjeringsnotat, "Samarbeide med Kina på energiområdet," November 29, 1978, Dc 0001, Bjartmar Gjerde’s Papers, Arbeiderbevegelsens arkiv og bibliotek.

65. Minutes of Prime Minister Nordli's conversation with Deputy Premier Kang Shi'en, Monday June 2, 1980, "Norge-Kina Statsminister Nordlis samtale med visestatsminister Kang Shi'en, mandag 2 . juni 1980," June 5, 1980, Olje- og energisamarbeid Norge og Kina, Bind 3, 1980, Utenriksdepartementets arkiv.

66. Lieberthal and Oksenberg, Policymaking in China, 46. Yu Qiuli (1914-1999) was a "Long March" veteran, minister for petroleum industry 1958-65, deputy-chief of the state planning commission 1964, top drafter of the third five-year plan 1965, vice-premier 1975, politburo member 1976, chairman of the state planning commission, head of the state energy commission 1980, deputy-secretary general of the general military commission, and director of the People's Liberation Army's general political department 1982-1987. Yu and Li Xiannian were the two most important figures in Chinese economic policy making during 1978. See Vogel, Deng Xiaoping, 221.

67. Statoil, memorandum, "Kinesisk offshorevirksomhet. Statoils konsulentavtale” [Chinese offshore oil activities and Statoil's consulting agreement], April 14, 1980, Kina notater 2, Ea-L0001, Pa-1339 Statoil ASA, Norsk olje- og gassarkiv, Statsarkivet i Stavanger. For Occidental's role, see Hammer, "On a Vast China Market," 19-25. Missing from the list of interested parties was Shell, a notable exception in that it demonstrates that IOC interest for China's continental shelf was not across the board.

68. Letnes and Moses, The Norwegian Experience, 58-87; Ryggvik, “A Short History of the Norwegian Oil Industry” 3-41; Ryggvik, The Norwegian Oil Experience, 23-38; Lie, Norsk økonomisk politikk etter 1905, 143-154. 
Both the development of hydropower and exploitation of the oil potential on China's continental shelf were important components in Deng's economic readjustment program dubbed "the Four Modernizations." ${ }^{69}$ Kang and his colleagues expressed to Gjerde that China desired to fully exploit its offshore petroleum reserves and that tentative experience from the Bohai Sea indicated that it needed further expertise in planning, exploration, field development, transport, and refining. ${ }^{70}$ While recognizing that Norway could offer assistance in these operative fields, Chinese officials showed more interest in the legal, regulatory, and fiscal aspects of the Norwegian model of oil governance and, most importantly, how Norway conducted contract negotiations with the IOCs. ${ }^{71}$ Kang, a geologist by profession, expressed two years later that "he long had entertained a personal interest for Norwegian petroleum policy and offshore activities and that the 'Statoil model' in particular had caught his interest." ${ }^{2} \mathrm{He}$ elaborated upon this point again in his confidential discussions with Norway's deputy minister for oil and energy Hans Henrik Ramm in 1982:

You have organised Statoil and this is a good idea. CNOOC is organised after this idea, but with small adjustments in order to account for China's social structures. We can also learn in other fields. We have also studied other countries, but in our opinion, Norway has the best solutions. The large oil companies complain about Norway, and this would suggest that you are doing a great job! These are the type of teachers we need! $!^{73}$

This is significant not only in terms of determining the organizational origin of CNOOC, but also in terms of how Deng had gained the support of the petroleum faction in 1977. He had destabilized Hua's support from the petroleum faction by "openly siding with the Oil Kingdom Faction in economic discussions," a group whose leading figure, Kang, had identified the "Norwegian model" as a way in which to restructure China's offshore oil industry. ${ }^{74}$

On the basis of these discussions, a memorandum of understanding was drawn up wherein Norway and China committed to "strengthening their co-operation within the energy sector."75 This cooperative aspect of the memorandum was, however, heavily tilted in

69. Energy formed one of the "Four Modernizations” of China's "New Long March." Speech, “Toast by Vice-Premier Kang Shi'en at Dinner Given by Norwegian Prime Minister Odvar Nordli,” June 10, 1980, Olje- og energisamarbeid Norge og Kina, Bind 3, 1980, Utenriksdepartementets arkiv. See also Mason, "China’s Four Modernizations," 47-70.

70. Gjerde, Regjeringsnotat, “Samarbeide med Kina på energiområdet,” November 29, 1978, Dc 0001, Bjartmar Gjerde’s Papers, Arbeiderbevegelsens arkiv og bibliotek.

71. Einar Risa, report, May 4, 1979, Kina notater 2, Ea-L0001, Pa-1339 Statoil ASA, Norsk olje- og gassarkiv, Statsarkivet i Stavanger.

72. Norsk Telegram Bureau (NTB), article entitled “Oljesamarbeid” [Oil cooperation], June 6, 1980, Olje- og energisamarbeid Norge og Kina, Bind 3, 1980, Utenriksdepartementets arkiv.

73. Kang Shien to Hans Henrik Ramm, March 21, 1982, Olje- og energisamarbeid Norge-Kina Bind 4, 198183, Utenriksdepartementets arkiv. See also Jakob Bleie, memorandum, December 9, 1981, Kina notater 2, EaL0001, Pa-1339 Statoil ASA, Norsk olje- og gassarkiv, Statsarkivet i Stavanger; also meeting with South China Sea Branch, March 23, 1982, Olje- og energisamarbeid Norge-Kina Bind 4, 1981-83, Utenriksdepartementets arkiv.

74. Fontana, "Fall of Hua Guofeng,” 248. See also: Mao, The Ebb and Flow of Chinese Petroleum, 316-317, 328-329.

75. Gjerde, Regjeringsnotat, “Samarbeide med Kina på energiområdet,” November 29, 1978, Dc 0001, Bjartmar Gjerde's Papers, Arbeiderbevegelsens arkiv og bibliotek. 
China's favor. Norway would assist in developing Chinese oil and gas fields in the Bohai Sea, as well as other regions, and would offer advanced technology for exploration and construction of installations; for seismic surveys and reviews; and for logistical bases, supply vessels, offshore rigs, production equipment, and pipelines. It would also provide consultancy services for offshore oil and gas exploration, contracts, financing, law-making, administration, and operations, "thus assist[ing] China in solving its problems in regard to its co-operation with the international companies in oil exploration and field development offshore."76

In return for this panoply of assistance, China expressed "a wish to use Norwegian goods and services," while promises of further orders had been made verbally. ${ }^{77}$ It was perhaps not without reason that Norway's Ministry for Oil and Energy (OED) by 1980 sought to deemphasize the economic importance of the cooperation in favor of the external aid dimension, specifically how the bilateral relationship promoted "knowledge transfers from industrialized to developing nations within the energy sector."78

Despite the lopsided nature of Sino-Norwegian industrial relations, the intention from the start was to "achieve a balance in the bilateral relationship that could be of benefit to both parties." As a gesture of good faith, Gjerde dispatched a delegation under the leadership of OED's permanent secretary Karl-Edwin Manshaus to China in April 1979 to chart the potential for Norwegian assistance. ${ }^{79}$ Since the signing of the first memorandum, Chinese officials had been pressing Norway to send a group of consultants, and this group, consisting of a geologist, a physicist, an economist, and a lawyer, was designated to begin the consultancy program. All were required to be state employees, which in practical terms meant either from the ministry, the Norwegian Petroleum Directorate, or Statoil. This insistence contributed to making Statoil the vehicle by which Norway would execute its "export promoting" policies vis-à-vis China. ${ }^{80}$

During the eleven days of meetings in April 1979, the government officials conveyed the details of Norwegian petroleum policy, with a particular emphasis on Norway's experiences during its initial phase of offshore exploration and production. ${ }^{81}$ Before their visit, the Norwegian delegation had translated the government's "blue book" of continental shelf legislation into Mandarin and later reported that "they had surmised that the Chinese were, in several instances, interested in copying the Norwegian regulations." ${ }^{2}$ China's partial adoption of Norwegian

76. Gjerde, Notat til regjeringskonferanse, March 28, 1979, Dc 0001, Bjartmar Gjerde’s Papers, Arbeiderbevegelsens arkiv og bibliotek.

77. Norwegian embassy in Beijing to Utenriksdepartementet, memorandum, "Samhandelen med Kina," May 2, 1980, Olje- og energisamarbeid Norge og Kina, Bind 3, 1980, Utenriksdepartementets arkiv; Gjerde to the Norwegian government, Notat til regjeringskonferanse, September 3, 1980, Dc 0001, Bjartmar Gjerde's Papers, Arbeiderbevegelsens arkiv og bibliotek.

78. Gjerde, Notat til regjeringskonferanse, September 3, 1980, Dc 0001, Bjartmar Gjerde’s Papers, Arbeiderbevegelsens arkiv og bibliotek.

79. Gjerde, Notat til regjeringskonferanse, March 28, 1979, Dc 0001, Bjartmar Gjerde’s Papers, Arbeiderbevegelsens arkiv og bibliotek.

80. Ibid.

81. Einar Risa, report, May 4, 1979, Kina notater 2, Ea-L0001, Pa-1339 Statoil ASA, Norsk olje- og gassarkiv, Statsarkivet i Stavanger.

82. Ibid. 
petroleum taxation law affirmed these assumptions. ${ }^{83}$ At this early stage, it was clear that China's priority lay in establishing the structures that would govern its offshore petroleum sector and "in choosing which model of licensing to adopt, be it service agreements, risk contracts or the socalled "Norwegian model." Statoil's representative reported that the delegation "had the impression" that China might "move in the direction" of adopting the latter. ${ }^{84}$

Sino-Norwegian petro-relations were further deepened in 1980 when China's vice-premier Kang visited Norway as part of his whistle-stop tour of international offshore locations in Europe and North America, in particular the British and Norwegian sectors of the North Sea, Washington, New York, Houston, and San Francisco. ${ }^{85}$ During his stop in Norway, Kang's delegation was duly flown by Statoil to the Statfjord A-platform, which in May 1980 was still operated by Mobil. ${ }^{86}$ One of the principal reasons for this worldwide fact-finding mission was to learn about offshore contracting, so the visit to the platform constructed and run by the IOC —due to be taken over by the domestic NOC in 1987-offered a pertinent demonstration of what China might also achieve in its negotiations with the IOCs. ${ }^{87}$

In advance of the vice-premier's visit, the Chinese government had indicated a set of topics it wanted its Norwegian hosts to elaborate upon. The first point concerned "the history of the exploration and opening-up of the North-Sea oil- and gas-fields and related experiences"; the second related to the development of land bases; while the third touched upon the institutional framework of resource governance: the "evaluation of resources, distribution of blocks, conditions on bids [...] administration of joint-ventures in the co-operation with foreign capital in exploring and constructing North-Sea oil-fields.” The fourth and final point concerned the fiscal arrangements: "how the state, in the course of co-operating with foreign capital, works out tax policy, classification of taxes, ways of collecting taxes and other related policies and decrees." ${ }^{88}$ The wish list betrayed the PRC's focus in its bilateral relationship: rather than Norwegian technical know-how per se, it was interested in how the Norwegian state had used the IOCs to serve its own purposes, striking a balance between maximizing government take on the one hand, while remaining sufficiently attractive for further investment on the other. ${ }^{89}$

83. Jakob Bleie, memorandum, December 9, 1981, Kina notater 2, Ea-L0001, Pa-1339 Statoil ASA, Norsk olje- og gassarkiv, Statsarkivet i Stavanger; also meeting with South China Sea Branch, March 23, 1982, Olje- og energisamarbeid Norge-Kina Bind 4, 1981-83, Utenriksdepartementets arkiv.

84. Einar Risa, report, May 4, 1979, Kina notater 2, Ea-L0001, Pa-1339 Statoil ASA, Norsk olje- og gassarkiv, Statsarkivet i Stavanger.

85. Taylor, The Chinese State, Oil and Energy Security, 91; Mao, The Ebb and Flow of Chinese Petroleum, 316-317.

86. Statoil Annual Report 1980, p. 6, https://www.equinor.com/no/investors/our-dividend/annualreports-archive.html.

87. Utenriksdepartementet to Norwegian embassy in Beijing, "Visestatsminister Kang Shiens besøk-endelig program,” May 27, 1980, Olje- og energisamarbeid Norge og Kina, Bind 3, 1980, Utenriksdepartementets arkiv.

88. Norwegian embassy in Beijing to Utenriksdepartementet, March 25, 1980, telegram entitled "Besøk i Norge av visestatsminister Kang Shi'en” [Visit to Norway by Deputy Premier Kang Shi'en], Olje- og energisamarbeid Norge og Kina, Bind 3, 1980, Utenriksdepartementets arkiv.

89. Lieberthal and Oksenberg, Policymaking in China, 219. "As another example, even as the Chinese were professing total ignorance about various forms of cooperation, they knew enough to seek advice from the very best officials of other governments, especially Norway." 
The result of Kang's visit was the drawing of a second bilateral memorandum aimed at "further strengthening energy cooperation" between the two states. China's first round of bidding on offshore blocks was about to commence, and the Chinese desired Norwegian consultation "on matters pertaining to bidding, terms and conditions of contracts, legislation, financing, evaluation of reserves etc." ${ }^{00}$ It was also hoped that Norway would "expand its consultation scope to engineering, technology, management, administration, etc." and assist in the development of land bases. ${ }^{91}$ In return, "priority" would be given to "purchasing from Norway on the basis of international competition" if certain equipment used in the offshore industry could not be sourced from China. ${ }^{92}$ While the promises made to Norwegian industry were still modest, Prime Minister Nordli, during his visit to Beijing, noted that Norway was "very flattered by the emphasis China placed on this cooperation" and that "the example of a Great Power cooperating with Norway, a country of four million, offers hope of a better coexistence between the world's large and small nations."93

The Sino-Norwegian petro-rapprochement led Western media to warn against "a hard-line Peking petroleum policy," as the allegedly "tough Norwegian state oil officials [were] whispering in China's ear about how to out-manoeuvre powerful Western oil companies." "94 The Australian newspaper Financial Review further speculated whether this would manifest itself as China “following Oslo's lead in dividing its southern offshore fields in a patchwork of small concessions and by employing the 'four group' consortium policy used so profitably by Norway."95

When China held its first licensing round in May 1982, licenses were awarded on the basis of production-sharing agreements requiring the IOCs to carry the entirety of exploration costs. ${ }^{96}$ The state's interests were represented by the newly created CNOOC, which held a 51 percent stake in each block, an ownership share that might be raised in case of a promising discovery; in addition to this came the levy of a 17.5 percent royalty. ${ }^{97}$ It was also stipulated that CNOOC was to "exploit offshore petroleum resources in cooperation with foreign enterprises," which in turn were mandated to "provide exploration investment, undertake

90. Sino-Norwegian memorandum, June 7, 1980, confidential, Olje- og energisamarbeid Norge og Kina, Bind 3, 1980, Utenriksdepartementets arkiv; memorandum "Samtalenotat-samarbeid innen petroleumssektoren,” September 3, 1980, Olje- og energisamarbeid Norge og Kina, Bind 3, 1980, Utenriksdepartementets arkiv.

91. Sino-Norwegian memorandum, June 7, 1980, confidential, Utenriksdepartementets arkiv, ss. 216-218; memorandum, "Samtalenotat-samarbeid innen petroleumssektoren" [Minutes of a conversation-cooperation within the petroleum sector], September 3, 1980, Olje- og energisamarbeid Norge og Kina, Bind 3, 1980, Utenriksdepartementets arkiv.

92. Ibid.

93. Speech by Norwegian prime minister, "Samarbeid innen petroleumssektoren" [Cooperation within the petroleum sector], September1, 1980, Olje- og energisamarbeid Norge og Kina, Bind 3, 1980, Utenriksdepartementets arkiv.

94. "Norwegians Coaching China-How to Beat the West on Oil," Financial Review, February 29, 1980.

95. Ibid.

96. "Kinesisk oljevirksomhet—samarbeid med Norge" [The Chinese petroleum industry—cooperating with Norway], May 30, 1984, Olje- og energisamarbeid Norge og Kina, Bind 5, 1983-86, Utenriksdepartementets arkiv.

97. Lieberthal and Oksenberg, Policymaking in China, 241. 
exploration operations and bear all exploration risks." 98 If China not had outright implemented a "Norwegian style" joint venture arrangement, it certainly had adopted a hybrid model, what Lieberthal and Oksenberg described as an "eclectic solution, heavily influenced by the Indonesian and Norwegian models." 99 The terms of China's petroleum contract echoed the contemporary Norwegian contractual hallmarks: bæring (carried interest) and glideskala (a sliding [equity] scale). ${ }^{100}$ Indeed, one of its main constituents, as Minister of Petroleum Kang Shien remarked in March 1982, CNOOC-formed the previous month-was both directly inspired by and modeled on Statoil. ${ }^{101}$

\section{Becoming an International National Oil Company: Statoil's Expansion into China, 1979-1989}

Whereas the Labor government viewed Statoil principally as a tool with which to promote the Norwegian offshore supply industry, the company itself minuted in a board meeting that it would participate in developmental aid work, as it was "economically sensible and would offer participating employees some international experience." ${ }^{102}$ Despite its status as a stateowned enterprise (SOE), Statoil exhibited a considerable and increasing degree of agency in its Chinese operations in the course of the 1980s. ${ }^{103}$ The difference between how the Norwegian and Chinese governments construed the NOC, as opposed to how Statoil itself defined its scope of operations and objectives, sheds light on the dynamics inherent to the process of statesponsored internationalization.

In December 1979, the first agreement between Statoil and China National Oil and Gas Exploration and Development Company (CNOGEDCO) was finalized. ${ }^{104}$ On this occasion, Statoil's CEO Arve Johnsen gave a speech at the reception dinner in Beijing. ${ }^{105}$ While paying tribute to China's long history of oil production, he noted that the country was "venturing on a new phase in the development of [its] petroleum resources," specifically operating offshore

98. Chapter 2, "Rights and Obligations of the Parties to Petroleum Contracts," Article 7 in China, "Regulations on the Exploitation of Offshore Petroleum Resources in Cooperation with Foreign Enterprises," 132-136.

99. Lieberthal and Oksenberg, Policymaking in China, 230, 235-239.

100. Carried interest was introduced in 1973 with Statoil's first concessions for the blocks $33 / 9$ and 33/12, where it was awarded a 50 percent stake. In 1992, carried interest was abandoned, although it only applied to foreign companies from 1983 onward. The concept of a sliding equity scale was introduced in 1974 and abandoned in 1993. This implied that the state's equity share (via Statoil) could be increased to a maximum of 80 percent in the event of a promising, commercial discovery. See Letnes and Moses, The Norwegian Experience, 58-87.

101. Kang Shien to Hans Henrik Ramm, March 21, 1982, Olje- og energisamarbeid Norge-Kina Bind 4, 198183, Utenriksdepartementets arkiv.

102. Statoil Board meeting minutes 1979-80, December 13, 1979, XA01 A 890806-XA01 A 900 158, AbbL0008, Norsk olje- og gassarkiv, Statsarkivet i Stavanger. That the motives behind engaging in and facilitating the government's industrial policy and external aid program derived from commercial considerations are corroborated by statements made to the author by Statoil's former CEO Arve Johnsen in an interview, May 27, 2018.

103. Interview with Jan Erik Langangen (Statoil's head of finance, 1979-1981), June 26, 2018.

104. Tancred Ibsen to Utenriksdepartementet, December 28, 1979, Olje- og energisamarbeid Norge og Kina, Bind 3, 1980, Utenriksdepartementets arkiv.

105. Johnsen, Norges evige rikdom, 202-203. 
and entering into comprehensive cooperative relationships with multinational oil companies. It was this combination that he acknowledged was the primary rationale behind Statoil's consultative involvement. ${ }^{106}$ Johnsen ended his speech by highlighting the importance of Norwegian industry's participation in China's offshore ventures and the fact that both Statoil and CNOGEDCO were SOEs, whose cooperation would foster stronger bilateral ties between the two countries. ${ }^{107}$ However, as is evident from Statoil's confidential correspondence of the early to mid-1980s, the company actively leveraged its NOC status to achieve its commercial objectives in the PRC. ${ }^{108}$

What distinguished Statoil's early years in China was its consultative role vis-à-vis the Chinese civil service, specifically as a pool of experience of how to negotiate with the IOCs. ${ }^{109}$ Until 1980, most of the consultation had been performed by the OED, but a lack of spare capacity led the Foreign Office to speculate whether Statoil would assume "more and more of the oil ministry's role' vis-à-vis the Chinese. ${ }^{110}$ Considered in the context of China's wider political economy, this illustrates the reasons why Chinese officials were so insistent on consultancy services and the positioning Statoil in this role. ${ }^{111}$ Access to advanced technology and expertise was a sine qua non to developing China's continental shelf and the Sixth Five Year Plan (19811985) specified that active foreign participation should be sought in offshore oil exploration. ${ }^{112}$

Statoil held a series of seminars in China through the early 1980s that covered most aspects of oil exploration and production offshore, but also subjects such as insurance, safety and contingency planning, accounting, and finance. ${ }^{113}$ The courses proved so popular that Statoil acceded to Chinese demands for institutionalizing the consulting role by establishing an office in Beijing with a view to also using it as a bridgehead to acquire offshore licenses. ${ }^{114}$ Then deputy-minister in OED, but future CEO of Statoil Harald Norvik opened the office in June 1981, and, considering Norvik's role in internationalizing the company during the 1990s, the ceremony marked in more ways than one the beginning of a new chapter in the company's

106. Arve Johnsen, speech in Beijing, December 17, 1979, Yae-L0003, Arve Johnsen Papers, Norsk olje- og gassarkiv. See also "Norway to Advise China on Oilfields," South China Morning Post, December 21, 1979.

107. Arve Johnsen, speech in Beijing, December 17, 1979, Yae-L0003, Arve Johnsen Papers, Norsk olje- og gassarkiv, Statsarkivet i Stavanger.

108. Memorandum entitled "Strategi for utvikling av virksomhet/engasjement utenlands" [Strategy for developing business overseas], May 5, 1982, Kina notater, Ea-L0001, Pa-1339 Statoil ASA, Norsk olje- og gassarkiv, Statsarkivet i Stavanger; Statoil report into establishing activities in China (Forstudie Statoil Etablering i Kina, 3. juli 1986), July 3, 1986, Statoil Papers, Ironmountain Box ID: 06.C95.253-87, Equinor Corporate Archive; also available from Ea-L0001, Pa-1339 Statoil ASA, Norsk olje- og gassarkiv, Statsarkivet i Stavanger.

109. "Norway to Advise China on Oilfields," South China Morning Post, December 21, 1979.

110. Memorandum, "Referat fra oppfølgingsmøte i Olje-og energidepartementet 4. januar 1980 vedrørende petroleumssamarbeidet med Kina” [Minutes of follow-up meeting at the Ministry of Petroleum January 4, 1980 regarding the petroleum partnership with China], January 7, 1980, Olje- og energisamarbeid Norge og Kina, Bind 3, 1980, Utenriksdepartementets arkiv.

111. Mao, The Ebb and Flow of Chinese Petroleum, 317-319.

112. Taylor, The Chinese State, Oil and Energy Security, 90.

113. Arne Langeland, Statoil report entitled"Rapport vedrørende Statoils virksomhet i Kina” [Report concerning Statoil's activities in China], March 11, 1981, Equinor Corporate Archive; Jakob Bleie, Kina notater 2, December 9, 1981, box ID 06.C95.253-87, Ea-L0001, Pa-1339 Statoil ASA, Norsk olje- og gassarkiv, Statsarkivet i Stavanger.

114. Interview with Jan Erik Langangen, June 26, 2018. 
history. ${ }^{115}$ With permanent representation, the company found itself among the plethora of NOCs, including Elf, Total, Japex, and BP, present in China, although the company still was barred from expanding its engagement into overseas upstream activities. ${ }^{116}$

A formal presence was, however, also useful to Statoil. As the Beijing office's first head, Agnar Langeland noted: "Through meetings and seminar series we have also gained insight into CNOGEDCO's organizational structure and general competence-level." 117 His findings indicated there was a lot left to be desired on the part of his Chinese counterparts, who were characterized as lacking in organizational abilities, maintained an overly centralized decisionmaking structure, and exhibited low levels of commercial professionalism. ${ }^{118}$ Langeland construed this as a boon, however, as it would ensure that Statoil could maintain a presence in China based on its educational program.

Equally, the improvement in skills was thought to ease Sino-Norwegian cooperation and enabled Statoil to "demonstrate its expertise and build personal connections with Chinese decision-makers." 119 The latter two observations were of particular importance. "Statoil was in many ways in a unique position in China," emphasized Langeland in his report, "since no other oil company in the world apart from Statoil had managed to enter into a commercial relationship with the Chinese." ${ }^{120}$ What he referred to was the fact that CNOGEDCO paid for the consulting services rendered by Statoil at undisclosed "international consultancy rates" as opposed to the free seminars provided by the other companies. ${ }^{121}$

The exclusivity of the arrangements suggests that Statoil did in fact enjoy a privileged position in China and that Statoil's Chinese clients thought the company possessed technology and expertise of value to their own development. Additionally, Statoil ran no financial risk by maintaining relations with its NOC counterpart; it built mutual trust through its seminars and garnered commercially sensitive information about China's future cooperation with IOCs. ${ }^{122}$ All of which would prove useful should the company be permitted to grasp the commercial opportunities inherent to the opening of China's markets to foreign investment.

Because Statoil was still formally barred from operating outside the Norwegian NCS, it did not feature among the list of 33 applicants and 102 applications when China held its first offshore licensing round in 1982. ${ }^{123}$ Neither could it accept the promising offshore blocks China's new minister for petroleum Tang Ke had offered Statoil on his visit to Norway in

115. Status (Statoil's internal newspaper), 1981 3, no. 3 (1981): 12-25, https://www.nb.no/nbsok/nb/ 31e8f006eadc05ebb03493f8e12a220e?index=2\#11.

116. UDs 2. økonomiske kontor to Statsekretær Eivinn Berg, memorandum, September 26, 1983, Olje- og energisamarbeid Norge og Kina, Bind 5, 1983-86, Utenriksdepartementets arkiv.

117. Arne Langeland, Statoil report entitled "Rapport vedrørende Statoils virksomhet i Kina," March 11, 1981, Equinor Corporate Archive, also available from: Ea-L0001, Pa-1339 Statoil ASA, Norsk olje- og gassarkiv, Statsarkivet i Stavanger.

118. Ibid.

119. Ibid.

120. Ibid.

121. "Norway to Advise China on Oilfields," South China Morning Post, December 21, 1979.

122. Arne Langeland, Statoil report entitled "Rapport vedrørende Statoils virksomhet i Kina," March 11, 1981, Equinor Corporate Archive, also available from: Ea-L0001, Pa-1339 Statoil ASA, Norsk olje- og gassarkiv, Statsarkivet i Stavanger.

123. Minutes of meeting with Ministry of Petroleum Industry, September 7, 1982, Olje- og energisamarbeid Norge-Kina Bind 4, 1981-83, Utenriksdepartementets arkiv. 
1983. ${ }^{124}$ Tang had come on a return visit after Norway's minister for oil and energy, Vidkunn Hveding, had visited China in 1982 and had been informed by CNOOC's president Qin Wen Cai that the "international companies had complained that the Chinese terms had derived from the Norwegian standard contract." ${ }^{125}$ Hence, as late as 1982-1983, the Sino-Norwegian petroleum rapprochement was primarily on a bilateral basis; the commercial aspect emerging once Statoil was given permission to expand operationally overseas.

Statoil's CEO Arve Johnsen had from the company's foundation in 1972 conceived of it as a vertically integrated, IOC. ${ }^{126}$ The missed licensing rounds in China and Denmark spurred management to consider overseas expansion more concretely. ${ }^{127}$ Statoil deduced that an international diversification of its reserve and production portfolio would minimize the risk to disruptions downstream and provide it with access to "low-cost oil." ${ }^{128}$ Further, it was thought that an international engagement would improve the company's stock of personnel deployable to the NCS. ${ }^{129}$ In this respect, Statoil to some extent mirrored the behavior of its private Norwegian counterpart, Saga, which used international operations-and the practical experience thus ostensibly garnered-to position the company for domestic NCS concessions. ${ }^{130}$ The company set out an ambitious expansion strategy: it wanted "[to acquire] assets and become an operator for petroleum fields by 1990," and the regions it had identified as most suitable were in the Middle East, China, and West Africa. ${ }^{131}$

Despite its marginal role as a consultant for CNOGEDCO, Statoil viewed this as simply the first step on a five-rung ladder that eventually would lead to the coveted prize of operator. ${ }^{132}$ Statoil's biggest obstacle in realizing these ambitions was not so much rival oil companies or Chinese licensing authorities, but its own government and owner who still prevented it from engaging in commercial upstream operations outside Norway. ${ }^{133}$

Norwegian authorities worried that an expansion of Statoil's activities in China would prejudice its position as an impartial advisor, which in turn would reduce its capacity to garner Chinese orders from Norwegian offshore suppliers. Manshaus noted in January 1980 that "Statoil would not be interested in acquiring an operatorship on the Chinese continental shelf" and dismissed speculations over whether Statoil would expand its commercial engagement in China: "This was not the intention," as an operative role would prejudice Statoil's neutrality as a

124. "Statoil søker i andre land?,” Norges handels- og sjøfartstidene, September 23, 1983.

125. Minutes of meeting with CNOOC, September 8, 1982, Olje- og energisamarbeid Norge-Kina Bind 4, 1981-83, Utenriksdepartementets arkiv.

126. Interview with Arve Johnsen (Statoil's CEO 1972-1988), May 28, 2018; Johnsen, Norges evige rikdom, $168-173$.

127. "Statoil søker i andre land?,” Norges handels- og sjøfartstidene, September 23, 1983.

128. Memorandum entitled "Strategi for utvikling av virksomhet/engasjement utenlands" [Strategy for developing business overseas], May 5, 1982, Kina notater, Ea-L0001, Pa-1339 Statoil ASA, Norsk olje- og gassarkiv, Statsarkivet i Stavanger.

129. Ibid.

130. Ryggvik, De tre bukkene, 37-46; Ryggvik, Til siste dråpe, 117-133.

131. Memorandum entitled "Strategi for utvikling av virksomhet/engasjement utenlands" [Strategy for developing business overseas], May 5, 1982, Kina notater, Ea-L0001, Pa-1339 Statoil ASA, Norsk olje- og gassarkiv, Statsarkivet i Stavanger.

132. Ibid.

133. UDs 2. økonomiske kontor to Statsekretær Eivinn Berg, memorandum, September 26, 1983, Olje- og energisamarbeid Norge og Kina, Bind 5, 1983-86, Utenriksdepartementets arkiv. 
consultant. ${ }^{134}$ However, as a tactic "to gain permission" for an expansion program, Statoil identified that an international operatorship would act precisely as "a door opener for Norwegian goods and services more generally." ${ }^{135}$ And by casting itself in the role of a champion for Norwegian businesses and industry abroad—an overseas industrial bridgehead—Statoil hoped to gain government sanction for a large-scale internationalization strategy. ${ }^{136}$

In 1983, Kåre Kristiansen, Norway’s new minister for petroleum and energy, faced questions in Parliament over his refusal of Statoil's requests for engaging in upstream activities on the Danish and Chinese continental shelves. ${ }^{137}$ Kristiansen denied that he had made any such representations to the company, retorting that the expansion plans had never been formally presented to him in the mandated annual public briefings of Statoil's plans (the so-called paragraph ten statute) or voted upon at the annual general assembly. ${ }^{138}$ Importantly, Kristiansen expressed that he viewed the proposition with favor and that both the matter of Statoil's China plans and the overarching question over whether the company should be allowed to pursue a wider internationalization strategy would be dealt with by Parliament early the next year. ${ }^{139}$ Statoil's lobbying bore fruit in 1984 when the Norwegian Parliament passed White Paper No. 73 (1983-1984), proposed by Willoch's conservative government, permitting the company to "actively participate in petroleum production abroad." ${ }^{140}$ Although it was too late for China's first licensing round, it opened the door for participating in the next.

Having finally received political sanction, Statoil showed remarkable restraint in exploiting the opportunities of the Chinese continental shelf, what CEO Johnsen as late as October 1983 had described as "the most promising and interesting in the world." ${ }^{141}$ Less than a year later, the results of the exploratory drilling had nevertheless proved disappointing. Of the eight wells drilled by BP, Esso, and Occidental, only two were reported to contain "traces of oil"; the rest were dry. To avoid the IOCs deserting China, a second licensing round was scheduled for the end of 1984. Even Premier Zhao Ziyang had on his visit to Norway in 1984

134. Memorandum, "Referat fra oppfølgingsmøte i Olje-og energidepartementet 4. januar 1980 vedrørende petroleumssamarbeidet med Kina” [Minutes of follow-up meeting at the Ministry of Petroleum January 4, 1980 regarding the petroleum partnership with China], January 7, 1980, Olje- og energisamarbeid Norge og Kina, Bind 3, 1980, Utenriksdepartementets arkiv.

135. Memorandum entitled "Strategi for utvikling av virksomhet/engasjement utenlands" [Strategy for developing business overseas], May 5, 1982, Kina notater, Ea-L0001, Pa-1339 Statoil ASA, Norsk olje- og gassarkiv, Statsarkivet i Stavanger.

136. Ibid.

137. Question in Parliament, Guttorm Hansen to the minster of petroleum regarding Statoil's activities in China (Grunngitt spørsmål fra Guttorm Hansen til olje- og energiministeren om Statoilengasjement i Kina), October 28, 1983, Olje- og energisamarbeid Norge og Kina, Bind 5, 1983-86, Utenriksdepartementets arkiv.

138. Draft answer to question raised in Parliament by Guttorm Hansen regarding China (Utkast til svar i Stortinget på spørsmål fra Guttorm Hansen ang. Kina), October 26, 1983, Olje- og energisamarbeid Norge og Kina, Bind 5, 1983-86, Utenriksdepartementets arkiv.

139. Ibid.

140. St.meld. nr. 73 (1983-84), “Om statens deltagelse i petroleumsvirksomheten” [Parliamentary White Paper regarding the state's participation in the petroleum sector], p. 28: "En omorganisering av statsdeltagelsen bør legge forholdene til rette for Statoil til å delta aktivt i petroleumsvirksomhet i utlandet” [A reorganization of the state's participation should prepare the ground for Statoil to expand internationally].

141. Draft answer to question raised in Parliament by Guttorm Hansen regarding China (Utkast til svar i Stortinget på spørsmål fra Guttorm Hansen ang. Kina), October 26, 1983, Olje- og energisamarbeid Norge og Kina, Bind 5, 1983-86, Utenriksdepartementets arkiv. 
expressed hope that Statoil would upgrade its China engagement from advisor to producer and participate in this round. ${ }^{142}$

Despite the premier's intervention and Statoil's participation, Norway's NOC was not awarded any blocks in this second round. ${ }^{143}$ Together with Elf Aquitaine and Cluff Oil, it had bid for a block in which it would be operator and own 40 percent. The license was awarded the Japanese company Japex, and Norwegian diplomats speculated whether the block had been "too promising" for the relatively inexperienced Statoil, who thus could not use the argument that it was a "high-risk block." 144 While the bidding was unsuccessful, Statoil attempted to gain a foothold on the Chinese shelf by purchasing ownership shares in two licenses. The first of these constituted 10 percent of a license operated by Total in the Gulf of Tonkin. The block already had limited output, and full-scale production was estimated to begin in August 1986. ${ }^{145}$ The other license was a block in the Yellow Sea that had originally been awarded to the minuscule British oil company, Cluff Oil. Statoil purchased a 55 percent ownership share and assumed the operatorship. ${ }^{146}$ Concurrently, China opened for foreign participation onshore in 1985, but Statoil did not take advantage of this offer.

Five years into Statoil's Far Eastern venture, the company was evidently reconsidering its enthusiasm for pulling chestnuts out of the Chinese fire for Norwegian industry. It was probably not a coincidence that this reassessment coincided with a lowered likelihood of discovering significant hydrocarbon reserves on the Chinese continental shelf. Statoil estimated the probability of making commercial discoveries in the Yinggehai basin to be between 14 and 24 percent, but that it was both "expensive and complicated" to run operations in the country. ${ }^{147}$

By 1987, most of Statoil's and indeed the IOCs' hopes for the Chinese continental shelf had been dashed, despite the license operated by Total producing 10,000 bbl/d, accounting for a full third of China's total offshore output. ${ }^{148}$ The well Statoil had drilled under its Yellow Sea license had proven to be dry. Global oil prices had plummeted, rendering even erstwhile commercially viable discoveries unprofitable. ${ }^{149}$ A final block south of Hainan in the South China Sea was awarded to Statoil as a gesture of good faith during Prime Minister Brundtland's visit to China in January 1988. ${ }^{150}$ However, even this block-the size of eight North Sea

142. Norwegian embassy in Beijing to Utenriksdepartementet, June 22, 1984, Olje- og energisamarbeid Norge og Kina, Bind 5, 1983-86, Utenriksdepartementets arkiv.

143. Stein Seeberg, memorandum, February 13, 1986, Olje- og energisamarbeid Norge og Kina, Bind 5, 1983-86, Utenriksdepartementets arkiv.

144. Memorandum, "Haugstvedt besøk i Kina” [Haugstvedt visit to China], April 16, 1986, Olje- og energisamarbeid Norge og Kina, Bind 6, 1986-90, Utenriksdepartementets arkiv; memorandum, February 7, 1986, Olje- og energisamarbeid Norge og Kina, Bind 5, 1983-86, Utenriksdepartementets arkiv.

145. Stein Seeberg, memorandum, February 13, 1986, Olje- og energisamarbeid Norge og Kina, Bind 5, 1983-86, Utenriksdepartementets arkiv.

146. Ibid.

147. Statoil report into establishing activities in China (Forstudie Statoil Etablering i Kina, 3. juli 1986), July 3, 1986, Statoil Papers, Ironmountain Box ID: 06.C95.253-87, Equinor Corporate Archive; also available from: Ea-L0001, Pa-1339 Statoil ASA, Norsk olje- og gassarkiv, Statsarkivet i Stavanger.

148. Memorandum entitled "Energipolitiske momenter" prepared for the prime minister's visit to China, January 1988, December 18, 1987, Olje- og energisamarbeid Norge og Kina, Bind 6, 1986-90, Utenriksdepartementets arkiv.

149. Ibid.

150. Press briefing, January 19, 1988, Olje- og energisamarbeid Norge og Kina, Bind 6, 1986-90, Utenriksdepartementets arkiv. 
equivalents—disappointed, and Statoil alerted the Norwegian Foreign Office in March 1989 of its intention to withdraw from China, closing its Beijing office in the process. ${ }^{151}$

As Statoil was winding down its operations in China, the student protests at Tiananmen Square erupted, compelling the company to issue a press release reporting its repatriation of its Norwegian staff. ${ }^{152}$ International condemnation of the Chinese human rights violations provided foreign oil companies a convenient excuse to withdraw from unprofitable investments, while alarming China's MPI over capital and technology flight. ${ }^{153}$ To stem the exodus following Total's withdrawal, Statoil was offered a new license on generous terms in the Gulf of Tonkin. ${ }^{154}$ Statoil accepted the offer shortly thereafter, but the Norwegian Foreign Office insisted that its operations had to "keep a low public profile and that it under any circumstances should be presented as a continuation of its existing commitments." ${ }^{155}$ In fact, Statoil remained an oil producer in China until 2009. In 1996, it acquired the Lufeng field that had been discovered by Occidental in the first licensing round of 1983. Considering the Chinese impetus behind the 1983-1984 white paper sanctioning Statoil's internationalization, it was perhaps also fitting that it was in the South China Sea that Statoil finally acquired its first international operatorship. ${ }^{156}$ When it divested its Chinese assets in 2009, they were sold to its partner, CNOOC, the company Statoil had served to inspire almost three decades earlier.

\section{Conclusion}

The Bay of Bohai and the South China Sea never became oil and natural gas provinces to rival the Gulf of Mexico or the North Sea. What was touted as "the world's richest petroleum reservoir" proved to be anything but. Yet the history of China's offshore sector as one of dashed expectations and meager returns has served to obscure its political and commercial significance: It was the promise of wealth rather than wealth itself that exerted a transformative effect on the parties involved.

Like Daqingism, which preceded it, China's great leap offshore had political and economic consequences that extended far beyond its petroleum industry. By opening the most important sector of its economy-the offshore sector-to foreign equity holdings, the PRC pioneered in the late 1970s the doctrinal shift that from 1981 officially became known as "reform and opening up." China's oil industry remained the pivot of its general production model: as the terrestrial oil industry had served as a Maoist model of economic organization, the offshore

151. Memorandum, Statoil in China, March 15, 1989, Olje- og energisamarbeid Norge og Kina, Bind 6, 198690, Utenriksdepartementets arkiv.; memorandum, Closure of Statoil's office in China, April 6, 1989, Olje- og energisamarbeid Norge og Kina, Bind 6, 1986-90, Utenriksdepartementets arkiv.

152. Statoil to the University of Oslo, July 12, 1989, Olje- og energisamarbeid Norge og Kina, Bind 6, 198690, Utenriksdepartementets arkiv.

153. Arne Walther, memorandum, July 28, 1989, Olje- og energisamarbeid Norge og Kina, Bind 6, 1986-90, Utenriksdepartementets arkiv.

154. Ibid.

155. Memorandum, Statoil's future position in China, August 8, 1989, Olje- og energisamarbeid Norge og Kina, Bind 6, 1986-90, Utenriksdepartementets arkiv.

156. Statoil acquired 75 percent of Lufeng 22-1 in 1996, with the remaining 25 percent share held by CNOOC; production began in the autumn of 1997. 
oil industry emerged as the spearhead for economic liberalization. The sheer technology- and capital-intensive nature of the offshore industry made this imperative, and China's deployment of "risk contracts" in the offshore industry was a policy derived from the petroleum faction. ${ }^{157}$ Rather than riding roughshod over this oil clique, Deng's reformist faction thus incorporated their "no-risk" policies into his economic readjustment program. ${ }^{158}$

In this new, post-Maoist political climate, China sought capital and technology from countries ranging from the United States, to Japan, to France, to the United Kingdom, to Norway, with Norway emerging as a partner. Norway's resource governance model-with its emphasis on maintaining sovereignty over reserves, high government take, low government financial risk through carried interest, and the facilitation of technology transfers through direct state participation via an NOC-offered incremental change along familiar political lines. The model thus turned the haunting specter of the ninteenth and early twentieth century system of unequal treaties on its head and reconciled Daqingist self-reliance with the means and methods of the international oil industry.

From a Norwegian perspective, the relationship was struck with a view at garnering orders for its struggling oil services industry, using its NOC Statoil as a bridgehead. Nor did Norway's agent in the bilateral relationship emerge unaltered from the Chinese crucible. It was in order to participate in China's second licensing round that Statoil was given parliament's approval to operate internationally, a decision that was to profoundly reshape the corporate body in the decades that followed. Statoil's reinvention as an IOC acted in turn as a fait accompli for its privatization and stock market listing and realigned the company's focus on upstream exploration and production.

Four decades on, both China's reaffirmation of reform and opening up and news of CNOOC's first fully independent offshore oil project reaching full production capacity offer lasting reminders of the Sino-Norwegian energy rapprochement. As this study has shown, Statoil served to inspire the creation of CNOOC under the auspices of petroleum minister and prominent oil clique member Kang Shien in February 1982. The use of Norwegian-inspired carried interest clauses neutralized CNOOC's exploration risk, and its controlling 51 percent interest in each block offered access to the IOCs' intellectual property and expertise. Despite the disappointing exploration efforts, CNOOC acquired a vast body of knowledge into the process of petroleum exploration and evaluation; learning that it bootstrapped to rapidly become an international player in the oil and gas business within the next decade, indeed a vehicle for the pursuit of Chinese energy security in the international arena. Although the immediate objective of the Chinese-the establishment of a major new offshore oil province-was a failure, the implementation of Norwegian licensing and governance model led to the rapid development of an internationally competitive CNOOC, due to the ensuing knowledge and technology transfers from the IOCs.

JONAS FOSSLI GJERSø is an associate professor of history at the University of Stavanger in Norway. Contact information: Department of Cultural Studies and Languages, University of Stavanger, P.O. Box 8600, 4036 Stavanger, Norway. E-mail: jonas.f.gjerso@uis.no.

157. Lieberthal and Oksenberg, Policymaking in China, 207, 252, 268; Mao, The Ebb and Flow of Chinese Petroleum, 328.

158. Vogel, Deng Xiaoping, 427-428. 


\section{Acknowledgment}

Earlier versions of this paper were presented at the Centre Universitaire de Norvège à Paris history workshop held in Paris, October 2018 and at the European Business History Association 23rd Annual Congress in Rotterdam, August 2019. I would like to thank my former colleagues at the University of Oslo's History of Statoil 1972-2022 project for their incisive comments on previous drafts and the three anonymous reviewers for greatly strengthening the paper's argument. Lastly, I would like to express my gratitude to my wife Carol Thanki and son Magnus Thanki Gjersø for their love, help and support. In memoriam Ole Kallelid (1967-2022).

\section{Bibliography of Works Cited}

\section{Books}

Chan, Leslie W. The Taching Oilfield: A Maoist Model of Economic Development. Canberra: Australian National University, 1974.

Eckbo, Paul Leo. The Future of World Oil. Cambridge: Ballinger, 1976.

Gordon, Richard, and Thomas Stenvoll. Statoil: A Study in Political Entrepreneurship. Houston, TX: Rice University, James A. Baker III Institute of Public Management, 2007.

Hobson, John M. The Eastern Origins of Western Civilisation. Cambridge: Cambridge University Press, 2004. Johnsen, Arve. Norges evige rikdom: oljen, gassen og petrokronene. Oslo: Aschehoug, 2008.

Kambara, Tatsu, and Christopher Howe. China and the Global Energy Crisis: Development and Prospects for China's Oil and Natural Gas. Cheltenham, UK: Edward Elgar, 2007.

Letnes, Bjørn, and Jonathan W. Moses. Managing Resource Abundance and Wealth: The Norwegian Experience. Oxford: Oxford University Press, 2017. 1

Feng, Lianyong Yan Hu, Charles A. S. Hall, and Jianliang Wang. The Chinese Oil Industry: History and Future. New York: Springer, 2013.

Lieberthal, Kenneth, and Michel Oksenberg. Policy Making in China: Leaders, Structures and Processes. Princeton, NJ: Princeton University Press, 1990.

Lie, Einar. Norsk økonomisk politikk etter 1905. Oslo: Universitetsforlaget, 2012.

Lim, Tai Wei. Oil in China:From Self-Reliance to Internationalization. Hackensack, NJ: World Scientific, 2010.

Ling, H. C. The Petroleum Industry in the People's Republic of China. Stanford, CA: Hoover Institution, 1975.

Mao, Huahe. The Ebb and Flow of Chinese Petroleum: A Story Told by a Witness. Boston: Brill, 2019.

Patey, Luke. The New Kings of Crude: China, India, and the Global Struggle for Oil in Sudan and South Sudan. Oxford: Oxford University Press, 2014.

Ryggvik, Helge. De tre bukkene: Saga, Norsk Hydro og Statoil: fra nasjonal beskyttelse til internasjonal ekspansjon. Oslo: Universitetet i Oslo, 1996.

— Til siste dråpe: om oljens politiske økonomi. Oslo: Aschehoug, 2010.

- The Norwegian Oil Experience: A Toolbox for Managing Resources? Oslo: Centre for Technology, Innovation and Culture, University of Oslo, 2010.

Taylor, Monique. The Chinese State, Oil and Energy Security. Basingstoke, UK: Palgrave Macmillan, 2014.

Vogel, Ezra. Deng Xiaoping and the Transformation of China. Cambridge, MA: Harvard University Press, 2011.

Zhang, Wei-Wei. Ideology and Economic Reform Under Deng Xiaoping 1978-1993. London: Routledge, 1996. 
Articles, Chapters in Books, Dissertations, Papers, and Reports

BP. Statistical Review of World Energy 2021, accessed February 1, 2021, https://www.bp.com/en/global/ corporate/energy-economics/statistical-review-of-world-energy.html.

Brødsgaard, Kjeld Erik. "Moving Ahead in China: State-Owned Enterprises and Elite Circulation.” China: An International Journal 18, no. 1 (2020): 107-122.

China. "Regulations on the Exploitation of Offshore Petroleum Resources in Cooperation with Foreign Enterprises." International Legal Materials 21, no. 1 (1982): 132-136. doi:10.1017/ S0020782900054954.

Fontana, Dorothy Grouse. "Background to the Fall of Hua Guofeng." Asian Survey 22, no. 3 (1982): 237-260.

Hama, Katsuhiko. “The Daqing Oil Field: A Model in China’s Struggle for Rapid Industrialization.” The Developing Economies 18, no. 2 (1980): 180-205.

Hammer, Armand. "On a Vast China Market.” Journal of International Affairs 39, no. 2 (1986): 19-25.

Högselius, Per. "The Saudi Arabia of the Far East? China's Rise and Fall as an Oil Exporter." Extractive Industries and Society 2, no. 3 (2015): 411-18.

Hong-Pyo, Lee. “China’s Petroleum Trade.” Journal of East Asian Affairs 4, no. 1 (1990): 184-221.

Kambara, Tatsu. "The Petroleum Industry in China.” The China Quarterly, no. 60 (1974): 699-719.

Mason, David. “China's Four Modernizations.” Asian Affairs: An American Review 11, no. 3 (1984): 47-70.

Ryggvik, Helge. "A Short History of the Norwegian Oil Industry: From Protected National Champions to Internationally Competitive Multinationals." Business History Review 89, no. 1 (2015): 3-41.

Stevens, Paul. "International Oil Companies: The Death of the Old Business Model." Chatham House Research Paper. London: Chatham House, May 2016.

Thomassen, Eivind. "The Crude Means to Mastery: Norwegian National Oil Company Statoil (Equinor) and the Norwegian State 1972-2001." Doctoral thesis, Department of Archaeology, Conservation and History, University of Oslo, Oslo, 2020.

Vatten, Anne. Skipsbygging - en saga blott? omstillinger i verftsindustrien. Sammendragsrapport nr 59. Bergen, Norway: Industriøkonomisk Institutt, 1986.

\section{Archives}

Arbeiderbevegelsens arkiv og bibliotek, Oslo, Norway

Equinor Corporate Archive, Stavanger, Norway

Norsk olje- og gassarkiv, Statsarkivet i Stavanger, Norway

Riksarkivet, Oslo, Norway

Utenriksdepartementets arkiv, Oslo, Norway

\section{Newspapers and Magazines}

Far Eastern Economic Review [1946-2009]

Financial Review [1951-]

Norges handels- og sjøfartstidene [1889-1987]

South China Morning Post [1903-]

Status Internavis for Statoil-ansatte [1974-2007]

Cite this article: Gjersø, Jonas Fossli. "The Great Leap Offshore: Sino-Norwegian Relations and PetroKnowledge Transfers, 1976-1997.” Enterprise \& Society (2022): 1-25. 